Bu makaleye atıfta bulunmak için/To cite this article:

ELKIRAN, Y. M. (2021). A Türkçe Öğretmeni Adaylarının Canlı Ders Etkileșim Düzeyi ile Ekran Okuma Özyeterlikleri Arasındaki İlişkinin İncelenmesi. Atatürk Üniversitesi Sosyal Bilimler Enstitüsü Dergisi, 25 (3), 12121231.

\title{
Türkçe Öğretmeni Adaylarının Canlı Ders Etkileşim Düzeyi ile Ekran Okuma Özyeterlikleri Arasındaki İlişkinin İncelenmesi
}

\author{
Yusuf Mete ELKIRAN (*)
}

Öz: Bu araştırmada Türkçe ögretmeni adaylarının canlı ders etkileşim düzeyleri ile ekran okuma öz yeterlikleri arasındaki ilişkiyi belirlemek amaçlanmıştır. Bu kapsamda Türkiye’nin batısındaki bir devlet üniversitesinin Türkçe öğretmenliği programındaki 210 öğretmen adayının yanıtları toplanmıştır. Araştırmada nicel araştırma yöntemlerinden ilişkisel tarama yönteminden yararlanılmıştır. Araştırmada veri toplama aracı olarak "Canlı Ders Etkileşim Düzeyi Belirleme Ölçeği " ve "Ekran Okuma Öz Yeterlik Algı Ölçeği " kullanılmıştır. Çalışmada aritmetik ortalama ve standart sapma değerleri ile Mann Whitney U ve Kruskal Wallis H-testi analizleri kullanılmıştır. Analizler doğrultusunda Türkçe eğitimi öğretmen adaylarının canlı ders etkileşim düzeyleri ile ekran okuma öz yeterliklerinin yüksek düzeyde olduğu sonucuna ulaşılmıştır. Cinsiyet, sınıf, akademik başarı ve internette geçirilen süre değişkenlerine göre canlı ders etkileşim düzeyleri ile ekran okuma öz yeterliklerinde anlamll fark görülmüşü̈r. Türkçe ögretmeni adaylarının canlı ders etkileşim düzeyleri ile ekran okuma öz yeterlikleri arasında zayıf düzeyde, pozitif yönde ve istatistiksel olarak anlamlı bir ilișki olduğu sonucuna ulașlmıștır.

Anahtar Kelimeler: Canlı ders etkileşimi, ekran okuma, Türkçe eğitimi

\section{Examining the Relationship between Prospective Turkish Teachers Online Course Interaction Level and Screen Reading Self-Efficacy Perception}

\begin{abstract}
The aim of this study is to examine the relationship between prospective Turkish teachers' online course interaction level and screen reading self-efficacy perception. In this context, the opinions of 210 Pre-Service Turkish Language Teachers of a state university in the west of Turkey were consulted. Relational screening method, which is one of the quantitative research methods, was used. Since it was determined that the data showed normal distribution due to the assumption analysis of the findings, Mann Whitney $U$ and Kruskal Wallis H-test analyses were used in the research. In addition to these parametric tests, mean scores and standard deviation scores of the descriptive analysis results were used. According to the analyzes, it was concluded that the online course interaction levels of the participants and their screen reading self-efficacy perception were at a high level. According to the gender, class, academic achievement and time spent on the internet, there was a significant difference in online course interaction levels and screen reading self-efficacy. It was concluded that there is a weak,
\end{abstract}

\footnotetext{
*) Öğretim Görevlisi, Çanakkale Onsekiz Mart Üniversitesi Eğitim Fakültesi Bilgisayar ve Öğretim Teknolojileri Eğitimi Bölümü (e-posta:ymelkiran@gmail.com) (DORCID ID. https://orcid.org/0000-0001-8372-8555

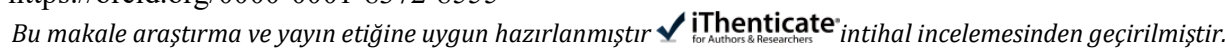


positive and significant relationship between the online course interaction level and screen reading self-efficacy perception.

Keywords: Online course interaction, screen reading, Turkish education

Makale Geliş Tarihi: 27.07.2021

Makale Kabul Tarihi: 20.09.2021

DOI: 10.53487/ataunisosbil.975316

\section{Giriş}

İnternet ortamında aynı anda öğrenenlerin ve öğreticinin anlık olarak görüntülü ve sesli olarak dijital bir ekran ve kamera üzerinden ders yapabildiği dersler canlı ders olarak adlandırılmaktadır. İnternet araç ve yazılımlarının kullanımından önce canlı ders denilince toplumda kitle iletişim aracı olan televizyondan canlı yayın dersler akla gelirdi. O dönemlerde genellikle Anadolu Üniversitesi Açık Öğretim Fakültesinin dersleri kayıt edilmiş videolar televizyonlar aracıllğı 1 ile öğrencilere öğrenim firsatı sunmak için kullanılırdı. İnternetin 21. yüzyılın ilk çeyreğinde internet ve internet araçlarının hem toplumlarda hem de eğitim öğretim kurumlarında kullanımının yaygınlaşması ile açık öğretim sistemleri internet temelli dijital altyapılara kaymış oldu. İlk başlarda lisansüstü eğitimde yaygınlaşan uzaktan öğretimde e-stüdyo donanımlarının kullanılması ve profesyonel kayıtlarla devam edilmesi planlanırken artan talepler ve eğiticilerin yoğun tempoları nedeniyle dersler veya ders kayıtları e-stüdyolar yerine evlerde belirlenmiş alanlarda doğrudan yapılarak sürdürülmüştür (Arat ve Bakan, 2011: 369). Bahsi geçen bu kurslar ve programlarda, öğrenme yönetim sistemleri üzerinden kayttlanarak ders materyallerine ulaşılması, ders kayıtları, sınavlar ile öğrenci işleri gibi birçok iş ve işlemler internete bağlı dijital araçlarla yapıldı. Bir düzenlemeye ihtiyaç duyulunca Yüksek Öğretim Kurumu (YÖK) tarafından yönetmelik yayınlanarak bu çerçevede usul ve esaslar belirlenmiştir (YÖK, 2013). Bazı üniversitelerde YÖK'ün verdiği izinlerle belirli kurslar ve yüksek lisans programları açıldı. Çevrimiçi eğitim öğretim süreçlerinde tüm paydaşlar bir ekran üzerinden iletişim kurarak yol aldılar. Bu sistemlerin bağlı olduğu dijital araçlar kimi zaman diz üstü veya masa üstü bilgisayarlar olurken kimi zamansa mobil araçlar olarak adlandırılan akıllı cep telefonları ve tabletler oldu. $\mathrm{Bu}$ eğitim öğretim süreçlerinde canlı derslere katılanlar diledikleri konular veya kaynaklarla ilgili belgelere daha rahat ulaşabilirken dilediklerinde de bu kaynakları basılı olarak okuma imkânına sahip oldular. Aynı zamanda kayıt altına alınan dersler arzu edildiğinde gün içerisinde istenilen zaman diliminde tekrar izlenebilme imkânına olanak tanıdı. Dersler kayıt altına alındıysa kayıtlar sonradan günün her saatinde arzu edildiği kadar tekrar izleme imkânına firsat verdi. Bu süreçte interneti ve sistemlere bağlanabilen dijital araçları olan öğrenciler eğitim öğretim faaliyetlerini sürdürebildiler.

2019 yılında covid-19 virüsü salgın hastalığı tüm dünyada yaygınlaşınca eğitim öğretimin tüm kademelerinde yüz yüze eğitime ara verildi. Türkiye'de kitle iletişim araçları kullanılarak eğitim öğretim faaliyetleri sürdürülmeye çalışıldı. Bu durumda öncelikle toplumda farklı gelir grupları olduğu düşünülerek her gruba firsat eşitliği sağlamak amacıyla TRT'de ilkokul, ortaokul ve lise için yayın hizmetleri verilmeye 
başlandı. Salgından önce dünyada çeşitli iş toplantıları ve kurslar için kullanılan bazı ismi bile duyulmamış internet sistemleri acilen derslerde yaygın olarak kullanılmaya başland. Toplumun her kesimi işlerini devam ettirebilmek için internet üzerinden toplantılar yapmak zorunda kaldı. İlk zamanlarda zorluklar yaşansa da zamanla hem sistemler gelişti hem de kullanıcılar duruma alışmak zorunda kaldılar. Türkiye'de 20192020 Bahar ve Güz ile 2020-2021 Bahar dönemlerinde öğrenciler, ekranların başında canlı derse katılma veya ders kaydını izleme, doküman okuma, ödevler için araştırma yapma gibi öğrencilik iş ve işlemleri yaptılar. Eğitimin diğer paydaşları da mecburen aynı şekilde daha çok ekran başından katılım sağladılar.

Son yıllarda canlı seminer ve derslerin yoğunluğu arttı. Bu yoğunlukla beraber derslerin etkililiği, öğrencilerin katılım düzeyleri ve aktiflikleri, derse uygun planlamaların yapılması, sunumların ve paylaşılan materyallerin netliği ile anlaşılırlığı, beyaz tahtanın kullanılırlığı, konuşmaların açık ve netliği ile beden dilinin etkili kullanılması ve çevresel gürültüler gibi verimliliği etkileyen unsurlar ortaya çıktı. Eğitim öğretim süreçlerinde verimliliğin arttırılması için paydaşlardan veri toplayarak elde edilen bulgularla yine paydaşlara fayda sağlanması konularına "öğrenme analitikleri" odaklanmaktadır. Öğrenme analitikleri, bulgular arası istatistiki verilerin işlenmesi, var olan durumun ortaya konulması, yorumlanması ve geleceğe yönelik kararlar alınması gibi istatistik konuları ile yoğurulmuş yeni bir disiplin olarak karşımıza çıkmaktadır (Bozkurt, 2016: 60; F1rat, 2015: 871; Ifenthaler, 2017: 367; Tutsun, 2020: 249; Y1lmaz ve Yılmaz, 2020: 754). Çevrimiçi ortamlarda eğitim ve öğretimin süreçlerinin geliştirilmesi konularını irdeleyen bu alan içindeki harmanlanmış öğrenme, e-öğrenme, mobil öğrenme, ekran okuma, göz izleme, dijital ayak izi, dijital rozet, eğitsel ajan gibi kavramlar da eğitim tarihi için çok yenidir. Uzaktan eğitim hizmetlerinin SWOT analizleri kalitenin arttırılmasında önemli yöntemlerdendir (Ustabulut, 2021: 142). Analize en çok yardımcı olan otomasyon ise öğrenme yönetim sistemi üzerindeki verilerdir. İletişimde kanal öğesi olarak değerlendirilen yazı da her ne kadar aynı kuramlardan beslense de çevrimiçi sınıflardaki yazışmalardaki etkileşimler de dikkate alınmaktadır (Karatay, 2011: 1030). Sistemde kalma, derse girme, dersten ayrilma, toplam derse katılım süreleri canlı derste sorulara verilen tepkiler ve aktif olunan süreler ile ödevlerdeki sayfa, sözcük, karakter (boşluklu veya boşluksuz), paragraf sayılarının yoğunlukları gibi verilerin analizi söz konusudur. Analizlerin bulgularından hareketle iyileştirmeler yapılmaktadır.

Etkileşim, öğrenme analitiklerinin en öncelikli konusu olduğu gibi iletişim kuramının da temelini oluşturur. Etkili öğretim için hem çevrim içi hem de yüz yüze eğitimde en önemli odak noktası etkileşimdir. İletişim kuramındaki geri besleme öğesi de etkileşimin belirlenmesine yardımcı olmaktadır. Öğrenenin tepkileri, öğrenme sürecinde veya sonunda ölçme ve değerlendirmelerle etkileşim ile öğrenme durumu hakkında fikir vermektedir. Canlı derslerdeki etkileşim dört ana başlıkta incelenmektedir. Bunlar; 1) Öğrenci-Öğretmen arası etkileşim. 2) Öğrenci içerik arası etkileşim. 3) Öğrenci-Öğrenci arası etkileşim. 4) Öğrenci-Teknoloji (ara yüz, ekran) arası etkileşimlerdir (Karaman, 2015: 84). Canlı dersle ilgili etkileşim kuramlarına göre derste veya ders dişında öğrencilerin; geçmiş tecrübeleri, öğretenle, öğrenme materyalleriyle, teknoloji ve 
sistemle, ekranla ve kendi gibi sistemde olan diğer öğrencilerle etkileşimleri dersin verimliliği için en önemli göstergelerdir. Öğrencilerin bu göstergelere bağlı olarak düzeylerinin belirlenmesi ve bulgulara göre etkileşim düzeylerini destekleyici tedbirler alınması etkili öğretime ulaşılmasına yardımcı olacaktır.

Çevrim içi dersler için kullanılan tüm sistemler ekranlar üzerinden takip edilebilmektedir. Bilgi ve iletişim teknolojilerinin yeniliklerinden biri de yeni okuma türü olarak "ekran okuma" kavramıdır (Güneş, 2010: 2). Ekran okuma yeni medya ortamlarında yapılan okumadır. Günlük yaşamda TV, cep telefonu, yansı, beyaz eşya ekranları ve bilgisayar gibi ekranlardan hayatın normallerinin içinde farkında olmadan yapılan bir okuma olarak da düşünülebilir (Maden, 2012: 2). Süreç olarak okuma becerisi kapsamında değerlendirilse de zihinde basılı medya kaynaklarından farklı uyaranların etkisi okumayı olumsuz etkileyebilmektedir. Metinlerin tam olarak anlaşılmasında ekrana yayılması, hizalanması, animasyonlar, dikkati zorlayan olumsuz etkiler mevcuttur (Güneş, 2016: 5). Baştuğ ve Keskin'e (2012: 80) göre kâğıt okuma ile ekran okuma anlama, okuma hızı ve doğru okuma değişkenlerine göre kıyaslandığında kâğıt okuma daha etkilidir. Ekran okumada sayfalar arasında geçiş zorluğu, metne hızlı göz atamama sorunu ile not alma ve altını çizme gibi okuma tekniklerinde aksaklıklar yaşanabilmektedir (Baştuğ ve Keskin, 2012: 81; Güneş, 2010: 6). Kol ve Schcolnik'e (2000: 74) göre ekran okuma ile ilgili doğru stratejilerin eğitimi verildiğinde kâğıt okuma ile aynı seviyede okuma becerisine ulaşılabilir.

21. yüzyılın başlarında internetten uzaktan günümüzde ise ilköğretimden doktora öğrenimlerine, hayat boyu öğrenme kapsamında çeşitli kurumların sağladığı bireysel yetenek kurslarına kadar neredeyse her seviyede çevrimiçi canlı dersler verilmektedir. $\mathrm{Bu}$ kaçınılmaz dijital ortamlardan kaynaklı olarak bu araştırmada Türkçe öğretmen adaylarının canlı ders etkileşim düzeyleri ile ekran okuma öz yeterlikleri arasındaki ilişkiyi saptamak amaçlanmıştır. Bu amaca yönelik olarak aşağıdaki sorulara yanıt aranmıştır:

1. Katılımcıların canlı ders etkileşimleri ne düzeydedir?

2. Katılımcıların ekran okuma öz yeterlikleri ne düzeydedir?

3. Katılımcıların canlı ders etkileşimleri cinsiyet, sınıf ve akademik başarı değişkenlerine göre farklılaşmakta mıdır?

4. Katılımcıların ekran okuma öz yeterlikleri cinsiyet, sınıf ve akademik başarı değişkenlerine göre farklılaşmakta mıdır?

5. Katılımcıların canlı ders etkileşim düzeyleri ile ekran okuma öz yeterlikleri arasında bir ilişki var mı? 
Türkçe Öğretmeni Adaylarının Canlı Ders Etkileşim Düzeyi ile Ekran Okuma Özyeterlikleri Arasındaki İlişkinin İncelenmesi

\section{Yöntem}

\section{A. Araştırmanın Modeli}

$\mathrm{Bu}$ araştırma, Türkçe öğretmeni adaylarının akademik okuryazarlık düzeyleri ile teknoloji yeterliği öz-değerlendirmeleri arasındaki ilişkiyi incelemek için korelasyonel yöntemle ilişkisel tarama modelinde tasarlanmıştır. Tarama araştırması, belirli bir sınıfın algılanan niteliklerini anlamlandırabilmek için verilerin toplandığı araştırmalardır (Büyüköztürk, Kılıç Çakmak, Akgün, Karadeniz ve Demirel, 2011:231). Bu araştırmada Türkçe öğretmeni adaylarının dijital yazma tutumları ile dijital okuma eğilimleri, veri toplama aracında yer alan değişkenler arası ilişkiler incelenmiştir. İki ve daha çok sayıdaki değişkenin bir arada değişim varlığı veya derecesi İlişkisel tarama modellerinde belirlenmeye çalışıllmaktadır (Karasar, 2002: 79).

\section{B. Veri Toplama Araçları}

Kişisel Bilgi Formu, araştırmacı tarafından demografik verileri toplamak için oluşturulmuştur. Kişisel bilgi formu ile örneklem grubunun cinsiyet, sınıf, akademik başarı düzeyi ve bir gün için ortalama internette geçirilen vakit bilgilerinin toplanmıştır.

Karaman (2015) tarafından geliştirilen beşli likert tipi ölçek olan "Canlı Ders Etkileşim Düzeyi Belirleme Ölçeği” kullanılmıştır. Geliştirilen ölçek çok yetersizden çok yeterliye bir ve beş puan arasında puanlanan likert türündedir. Ölçme aracı toplam 14 madde ve dört alt boyuttan oluşmaktadır. Olumsuz madde bulunmamaktadır. Ölçme aracında 1, 2, 3, 4, 5 ile 6. maddelerden oluşan "öğretmenin öğrenci ile kurduğu sözlü etkileşim" faktörü "Öğrenci" olarak adlandırılmış; 7, 8 ve 9. maddelerden oluşan "Öğretmenin sözlü etkileşimi” faktörü “Öğretmen” olarak adlandırılmış; 10 ve 11. maddelerden oluşan "Öğretmenin içerik aracılığıyla sağladığı sözsüz etkileşim” faktörü "İçerik" olarak adlandırılmış; 12, 13 ve 14. maddelerden oluşan "Öğretmenin ders sunum şekli aracılığıyla sağladığı etkileşim” faktörü "sunum şekli” olarak adlandırılmıştır (Karaman, 2015). Bu araştırmada Canlı Ders Etkileşim Düzeyi Belirleme Ölçeğinin Cronbach-Alfa iç tutarlılık katsayısı .923 olarak hesaplanmıştır.

Ulu'nun geliştirdiği (2018) tarafından geliştirilen beşli likert tipi ölçek olan "Ekran Okuma Öz Yeterlik Algı Ölçeği” kullanılmıştır. Uyarlanan ölçek bir ile beş arasında likert türünde puanlamayı gerektirmektedir. Ölçme aracı toplam 16 madde ve dört alt boyuttan oluşmaktadır. 1, 3, 6, 7, 9 ve 15. maddeler olumsuz maddelerdir. Ölçme aracında 1, 2, 7, 8, 11 ve 12. maddeler "kullanışlılık" alt boyutunu; 3, 4 ve 5. maddeler "anlama" alt boyutunu; 6, 9 ve 10. maddeler "sayfayı yönetme" alt boyutunu; 13, 14, 15 ve 16. maddeler "göz sağlığı" alt boyutunu oluşturmaktadır. Puanlamada 1 puan "Benim için hiç uygun değil"; 2 puan "Benim için uygun değil”"; 3 puan "Kararsızım"; 4 puan "Benim için uygun"; 5 puan ise "Benim için tamamen uygun" olarak belirlenmiştir (Ulu, 2018). Bu araştırmada Ekran Okuma Öz Yeterlik Alg1 Ölçeği’nin Cronbach-Alfa iç tutarlılık katsayısı. 823 olarak hesaplanmıştır. 


\section{Verilerin Analizi}

Araştırmada tanımlayıcı istatistikler olarak aritmetik ortalama $(\overline{\mathrm{X}})$, frekans (f), yüzde (\%) ile standart sapma (Ss) verilerine SPSS programı üzerinden hesaplanmıştır. Ekran Okuma Öz Yeterlik Alg1 Ölçeği’nin ve Canlı Ders Etkileşim Düzeyi Belirleme Ölçeği’nin basıklık ve çarpıklık değerleri -2 ile +2 arasında değildir. Bu çerçevede verilerin -2 ile +2 aralığının dışında değer alması dikkate alındığında bu araştırmada analizler için non-parametrik testler kullanılmıştır (George ve Mallery, 2010). Basıklık ve çarpıklık verilerinden hareketle Kruskal Wallis H-testi, Mann Whitney U ve Spearman korelasyon analizi kullanılmıştır. Ölçme araçlarından edilen puanların ortalamasından 1-2.33 puan arası "düš̈̌k seviye" ile 2.33-3.66 puan aralığı "orta seviye", 3.66-5.0 puan aralığı "yüksek seviye" etkileşim düzeyi olarak değerlendirilmiştir.

\section{Araştırmanın Örneklem Grubu}

Araştırmanın örneklemini Çanakkale Onsekiz Mart Üniversitesinde 2020-2021 eğitim öğretim yılı bahar yarıyılında Türkçe öğretmenliği programında öğrenim gören 210 öğrenci oluşturmaktadır. Araşıırmanın örnekleme ait tanımlayıcı istatistikî veriler aşağıda verilmiştir.

Tablo 1: Örneklemi Oluşturan Türkçe Öğretmeni Adaylarının Cinsiyetleri

\begin{tabular}{ccc}
\hline Cinsiyet & f & \% \\
\hline Kadin & 164 & 78.1 \\
Erkek & 46 & 21.9 \\
\hline
\end{tabular}

Tablo 1'de görüldüğü üzere araştırmanın katılımcılarının \%78.1'inin kadın, \% 21.9'unun erkek olduğu görülmektedir.

Tablo 2: Örneklemi Oluşturan Türkçe Öğretmeni Adaylarının Sınıf Düzeyleri

\begin{tabular}{ccc}
\hline Sinif & f & \% \\
\hline 1. Sinif & 42 & 20.0 \\
2. Sinif & 34 & 16.2 \\
3. Sinif & 61 & 29.0 \\
4. Sinif & 73 & 34.8 \\
\hline
\end{tabular}

Tablo 2'de görüldüğü üzere araştırmaya katılanların \%20.0'sinin birinci sınıf, \%16.2'sinin ikinci sınıf, \%29.0'unun üçüncü sınıf, \%34.8'inin ise dördüncü sınıf olduğu görülmektedir.

Tablo 3: Örneklemi Oluşturan Türkçe Öğretmeni Adaylarının Akademik Başarı Ortalamaları

\begin{tabular}{ccc}
\hline Not Ortalamalari & f & \% \\
\hline 0-2,49 Puan & 11 & 5.2 \\
2,50-2,99 Puan & 48 & 22.9 \\
3,00-4,00 Puan & 151 & 71.9 \\
\hline
\end{tabular}


Tablo 3'te görüldüğü üzere araştırmaya katılanların \%5.2'sinin 0-2.49 puan, \%22.9'unun 2.50-2.99 puan arası ve \% 71.9'unun 3.00-4.00 puan arası not ortalamasina sahip olduğu görülmektedir.

Tablo 4: Örneklemi Oluşturan Türkçe Öğretmeni Adaylarının Günlük Ortalama İnternette Geçirdikleri Süre

\begin{tabular}{ccc}
\hline Saat & f & \% \\
\hline $0-2$ & 16 & 7.6 \\
$2-4$ & 86 & 41.0 \\
$4-6$ & 88 & 41.9 \\
6 ve üzeri & 20 & 9.5 \\
\hline
\end{tabular}

Tablo 4'te görüldüğü üzere araştırmaya katılanların \%7.6'sının 0-2 saat, \%41.0'inin 2-3 saat, \%41.9'unun 4-6 saat, \%9.5'inin ise altı ve altı üzeri saat boyunca bir günde ortalama internette zaman geçirdikleri görülmektedir.

\section{E. Etik Kurulu İzni}

Araştırmada uygulanan ölçekler kullanılmadan önce ölçekleri uyarlayan araştırmacılardan e-posta yoluyla kullanım izni alınmıştır. Araştırma bir Eğitim Fakültesi'nde öğrenim gören öğretmen adaylarıyla gerçekleştiği için bu Eğitim Fakültesi'nden ölçeklerin uygulanmasıyla ilgili resmi olarak yazı ile izin alınmıştır. Çanakkale Onsekiz Mart Üniversitesi Sosyal Bilimler ve Eğitim Bilimleri Etik Kurulu 04.12.2020 tarih, 06/46 sayılı kararı ile araştırmanın bilimsel etik kurallara uygun olduğu kararı verilmiştir.

\section{Bulgular}

Tablo 5: Türkçe Öğretmeni Adaylarının Ekran Okuma Öz Yeterliklerinin Analiz Sonuçları

\begin{tabular}{lccc}
\hline Boyutlar ve Ölçek & N & $\overline{\mathrm{X}}$ & $\mathbf{S}$ \\
\hline Kullanışlılık Boyutu & 210 & 4.49 & .32 \\
Anlama Boyutu & 210 & 4.47 & .35 \\
Sayfayı Yönetme Boyutu & 210 & 4.17 & .39 \\
Göz Sağlı̆̆ı Boyutu & 210 & 4.33 & .49 \\
Ekran Okuma Öz Yeterliği & 210 & 4.39 & .31 \\
\hline
\end{tabular}

Tablo 5'te görüldüğü üzere, katılımcıların ekran okuma öz yeterliklerinin ortalama beş üzerinden $\overline{\mathrm{X}}=4.39$ ile yüksek düzeyde olduğu ve "Benim için uygun" şeklinde yanıtladıkları görülmektedir. Ölçeğin "Kullanışlılık" alt boyutuna yüksek düzeyde $(\bar{X}=4.49)$, "Anlama" alt boyutuna yüksek düzeyde $\bar{X}=4.47$, "Sayfayı Yönetme" alt boyutuna yüksek düzeyde $(\bar{X}=4.17)$ ve "Göz Sağlığı" alt boyutuna yüksek düzeyde $(\bar{X}=4.33)$, ekran okuma algılarının yüksek düzeyde olduğu görülmektedir. 
Tablo 6: Türkçe Öğretmeni Adaylarının Canlı Ders Etkileşim Düzeyi Analiz Sonuçları

\begin{tabular}{lccc}
\hline Boyutlar ve Ölçek & $\mathbf{N}$ & $\overline{\mathbf{X}}$ & $\mathbf{S}$ \\
\hline Öğgrenci Boyutu & 210 & 4.74 & .44 \\
Öğretmen Boyutu & 210 & 4.73 & .46 \\
İçerik Boyutu & 210 & 4.88 & .32 \\
Sunum Şekli Boyutu & 210 & 4.58 & .55 \\
Canlı Ders Etkileşim Düzeyi Belirleme Ölçeği & 210 & 4.72 & .39 \\
\hline
\end{tabular}

Tablo 6'da görüldüğg̈ üzere, katılımcıların canlı ders etkileşim düzeylerinin ortalama beş üzerinden $\bar{X}=4.72$ ile yüksek düzeyde olduğu ve "Çok yeterli" șeklinde yanıtladıkları görülmektedir. Bununla beraber Canlı Ders Etkileşim Düzeyi Belirleme Ölçeği'nin "Öğrenci" alt boyutunda ( $\bar{X}=4.74)$, "Öğretmen" alt boyutunda $(\bar{X}=4.73)$ ve "İçerik" alt boyutunda $(\overline{\mathrm{X}}=4.88)$ ve "Sunum şekli" alt boyutunda $(\overline{\mathrm{X}}=4.58)$ etkileşim algılarının yüksek düzeyde olduğu görülmektedir.

Katılımcıların ekran okuma öz yeterlik algıları ile canlı ders etkileşim düzeylerinin cinsiyet değişkenine göre farklılık durumunu anlamak için Mann Whitney U uygulanmış ve sonuçlar Tablo 7 ve Tablo 8'de görülmektedir.

Tablo 7: Türkçe Öğretmeni Adaylarının Ekran Okuma Öz Yeterlik Algı Düzeylerinin Cinsiyet Değişkenine Göre Mann-Whitney U Testi Analiz Sonuçları

\begin{tabular}{|c|c|c|c|c|c|c|}
\hline Boyutlar & Grup & $\mathbf{n}$ & $\begin{array}{c}\text { Sira } \\
\text { Ortalamasi }\end{array}$ & $\begin{array}{c}\text { Sira } \\
\text { Toplamı }\end{array}$ & $\mathbf{U}$ & $\mathbf{p}^{*}$ \\
\hline \multirow[t]{2}{*}{ Kullanışl1lık } & Kadın & 164 & 89.81 & 14729.50 & \multirow[t]{2}{*}{1199.50} & \multirow[t]{2}{*}{.000} \\
\hline & Erkek & 46 & 161.42 & 7425.50 & & \\
\hline \multirow[t]{2}{*}{ Anlama } & Kadın & 164 & 90.38 & 14822.50 & \multirow[t]{2}{*}{1292.50} & \multirow[t]{2}{*}{.000} \\
\hline & Erkek & 46 & 159.40 & 7332.50 & & \\
\hline \multirow{2}{*}{ Sayfayı Yönetme } & Kadın & 164 & 116.66 & 19132.00 & \multirow[t]{2}{*}{1942.00} & \multirow[t]{2}{*}{.000} \\
\hline & Erkek & 46 & 65.72 & 3023.00 & & \\
\hline \multirow[t]{2}{*}{ Göz Sağlığı } & Kadın & 164 & 89.57 & 14689.50 & \multirow[t]{2}{*}{1159.50} & \multirow[t]{2}{*}{.000} \\
\hline & Erkek & 46 & 169.29 & 7465.50 & & \\
\hline \multirow{2}{*}{$\begin{array}{l}\text { Ekran Okuma Öz Yeterlik Alg1 } \\
\text { Ölçeği }\end{array}$} & Kadın & 164 & 89.50 & 14677.50 & \multirow[t]{2}{*}{1147.50} & \multirow[t]{2}{*}{.000} \\
\hline & Erkek & 46 & 162.55 & 7477.50 & & \\
\hline
\end{tabular}

Tablo 7 dikkate alındığında ölçeğin tamamına göre Türkçe öğretmeni adaylarının ekran okuma öz yeterlik algı düzeylerinin cinsiyete göre erkeklerin lehine anlamlı bir fark göstermektedir [U $=1147.50, p<.05]$. Kullanışlılık, anlama ve göz sağlığı alt boyutlarında erkeklerin lehine anlamlı bir fark gösterirken sayfayı yönetme alt boyutunda ise kadınların lehine anlamlı bir fark göstermektedir $(\mathrm{p}<.05)$.

Tablo 8: Türkçe Öğretmeni Adaylarının Canlı Ders Etkileşim Düzeylerinin Cinsiyet Değişkenine Göre Mann-Whitney U Testi Analiz Sonuçları 
Türkçe Öğretmeni Adaylarının Canlı Ders Etkileşim Düzeyi ile Ekran Okuma Özyeterlikleri Arasındaki İlişkinin İncelenmesi

\begin{tabular}{|c|c|c|c|c|c|c|}
\hline Boyutlar & Grup & $\mathbf{n}$ & $\begin{array}{c}\text { Sira } \\
\text { Ortalaması }\end{array}$ & $\begin{array}{c}\text { Sira } \\
\text { Toplamı }\end{array}$ & $\overline{\mathbf{U}}$ & $\mathbf{p}^{*}$ \\
\hline \multirow[t]{2}{*}{ Öğrenci } & Kadın & 164 & 98.98 & 16232.50 & \multirow[t]{2}{*}{2702.50} & \multirow[t]{2}{*}{.001} \\
\hline & Erkek & 46 & 128.75 & 5922.50 & & \\
\hline \multirow[t]{2}{*}{ Öğretmen } & Kadın & 164 & 122.40 & 20073.00 & \multirow[t]{2}{*}{1001.00} & \multirow[t]{2}{*}{.000} \\
\hline & Erkek & 46 & 45.26 & 2082.00 & & \\
\hline \multirow[t]{2}{*}{ İçerik } & Kadın & 164 & 106.39 & 17448.00 & \multirow[t]{2}{*}{3626.00} & \multirow[t]{2}{*}{.051} \\
\hline & Erkek & 46 & 102.33 & 4707.00 & & \\
\hline \multirow[t]{2}{*}{ Sunum Şekli } & Kadın & 164 & 97.89 & 16053.50 & \multirow[t]{2}{*}{2523.50} & \multirow[t]{2}{*}{.00} \\
\hline & Erkek & 46 & 132.64 & 6101.50 & & \\
\hline \multirow[t]{2}{*}{ Canlı Ders Etkileşim Düzeyi } & Kadın & 164 & 106.67 & 17493.50 & \multirow[t]{2}{*}{3580.50} & \multirow[t]{2}{*}{.499} \\
\hline & Erkek & 46 & 101.34 & 4661.50 & & \\
\hline
\end{tabular}

$\mathrm{p}^{*<.05}$

Tablo 8 dikkate alındığında ölçeğin tamamına göre Türkçe öğretmeni adaylarının canlı ders etkileşim düzeylerinin cinsiyete göre anlamlı bir fark göstermemektedir [U = $3580.50, p>.05]$. Bununla beraber içerik alt boyutunda anlamlı bir fark göstermemektedir ( $>$ >.05). Öğrenci ve sunum şekli alt boyutlarında erkeklerin lehine anlamlı bir fark gösterirken öğretmen alt boyutunda ise kadınların lehine anlamlı bir fark göstermektedir $(\mathrm{p}<.05)$.

Türkçe öğretmeni adaylarının ekran okuma öz yeterlik algı düzeylerinin sınıf düzeyi değişkeni açısından farklılaşıp farklılaşmadığını belirlemek amacıyla Kruskal Wallis Htesti uygulanmıştır. Uygulanan testler sonucunda elde edilen sonuçlar Tablo 9' da gösterilmiştir.

Tablo 9: Türkçe Öğretmeni Adaylarının Ekran Okuma Öz Yeterlik Alg1 Düzeylerinin Sınıf Düzeyi Değişkenine Göre Kruskal Wallis H-testi Analiz Sonuçları

\begin{tabular}{|c|c|c|c|c|c|c|}
\hline Boyutlar & Gruplar & $\mathbf{N}$ & $\begin{array}{c}\text { Sira } \\
\text { Ortalaması }\end{array}$ & Sd & $X^{2}$ & $\mathbf{p}^{*}$ \\
\hline \multirow[t]{4}{*}{ Kullanışlılık } & 1.Sinif & 42 & 125.67 & 3 & 7.628 & .054 \\
\hline & 2.Sinıf & 34 & 96.71 & & & \\
\hline & 3.Sinif & 61 & 97.70 & & & \\
\hline & 4.Sinif & 73 & 104.51 & & & \\
\hline \multirow[t]{4}{*}{ Anlama } & 1.Sinıf & 42 & 112.89 & 3 & 4.109 & .250 \\
\hline & 2.Sinif & 34 & 108.90 & & & \\
\hline & 3.Sinif & 61 & 93.86 & & & \\
\hline & 4.Sinif & 73 & 109.39 & & & \\
\hline \multirow[t]{4}{*}{ Sayfayı Yönetme } & 1.Sinif & 42 & 110.54 & 3 & 5.483 & .140 \\
\hline & 2.Sinıf & 34 & 91.37 & & & \\
\hline & 3.Sinıf & 61 & 99.72 & & & \\
\hline & 4.Sinif & 73 & 114.01 & & & \\
\hline \multirow[t]{5}{*}{ Göz Sağllı̆g } & 1.Sinıf & 42 & 121.38 & 3 & 10.689 & $.014 *$ \\
\hline & 2.Sinıf & 34 & 96.29 & & & \\
\hline & 3.Sinif & 61 & 90.29 & & & \\
\hline & 4.Sinıf & 73 & 113.36 & & & \\
\hline & 1.Sinif & 42 & 123.19 & 3 & 9.373 & $.025^{*}$ \\
\hline
\end{tabular}


Ekran Okuma Öz
Yeterlik Alg1 Ölçeği $\mathrm{p}^{*<.05}$

Tablo 9'da görüldüğü üzere Türkçe öğretmeni adaylarının ekran okuma öz yeterlik alg1 düzeyleri sınıf düzeyine göre anlamlı farklılık göstermektedir [ $X^{2}(3)=9.373$; $\mathrm{p}<.05]$. Analizler sonucunda 1 ve 4 . sınıftaki katılımcıların ekran okuma öz yeterlik alg1 düzeylerinin 2 ve 3 . sinıftaki katılımcılara göre daha olumlu düzeyde olduğu söylenebilir. Bununla beraber göz sağlı̆̆1 alt boyutunda [ $\left.X^{2}(3)=10.689 ; \mathrm{p}<.05\right]$ ekran okuma öz yeterlik algı düzeyleri sınıf değişkenine göre 1 ve 4 . sınıftaki katılımcıların lehine 2 ve 3. sınıftaki katılımcılara göre daha olumlu düzeyde olduğu söylenebilir.

Türkçe öğretmeni adaylarının canlı ders etkileşim düzeylerinin sınıf düzeyi değişkeni açısından farklılaşıp farklılaşmadığını belirlemek amacıyla Kruskal Wallis H-testi uygulanmıştır. Uygulanan testler sonucunda elde edilen sonuçlar Tablo $10^{\prime}$ da gösterilmiştir.

Tablo 10: Türkçe Öğretmeni Adaylarının Canlı Ders Etkileşim Düzeylerinin Sınıf Düzeyi Değişkenine Göre Kruskal Wallis H-testi Analiz Sonuçları

\begin{tabular}{|c|c|c|c|c|c|c|}
\hline Boyutlar & Gruplar & $\mathbf{N}$ & $\begin{array}{c}\text { Sira } \\
\text { Ortalaması }\end{array}$ & Sd & $X^{2}$ & p* \\
\hline \multirow[t]{4}{*}{ Öğrenci } & 1.Sinif & 42 & 113.04 & 3 & 2.494 & .476 \\
\hline & 2.Sinif & 34 & 92.97 & & & \\
\hline & 3.Sinıf & 61 & 106.49 & & & \\
\hline & 4.Sinıf & 73 & 106.17 & & & \\
\hline \multirow[t]{4}{*}{ Öğretmen } & 1.Sinıf & 42 & 97.88 & 3 & 5.955 & .114 \\
\hline & 2.Sinıf & 34 & 90.99 & & & \\
\hline & 3.Sinif & 61 & 108.58 & & & \\
\hline & 4.Sinif & 73 & 114.07 & & & \\
\hline \multirow[t]{4}{*}{ İçerik } & 1.Sinif & 42 & 105.07 & 3 & 4.809 & .186 \\
\hline & 2.Sinif & 34 & 93.22 & & & \\
\hline & 3.Sinif & 61 & 108.39 & & & \\
\hline & 4.Sinif & 73 & 109.05 & & & \\
\hline \multirow[t]{4}{*}{ Sunum Şekli } & 1.Sinif & 42 & 109.45 & 3 & 4.354 & .226 \\
\hline & 2.Sinif & 34 & 87.24 & & & \\
\hline & 3.Sinif & 61 & 109.89 & & & \\
\hline & 4.Sinıf & 73 & 108.06 & & & \\
\hline \multirow{4}{*}{$\begin{array}{l}\text { Canlı Ders Etkileşim } \\
\text { Düzeyi }\end{array}$} & 1.Sinıf & 42 & 104.77 & 3 & 8.893 & $.031 *$ \\
\hline & 2.Sinıf & 34 & 84.82 & & & \\
\hline & 3.Sinıf & 61 & 114.39 & & & \\
\hline & 4.Sinif & 73 & 108.12 & & & \\
\hline
\end{tabular}

$\mathrm{p}^{*}<.05$

Tablo 10’da görüldüğü üzere Türkçe öğretmeni adaylarının canlı ders etkileşim düzeylerinin sınıf düzeyine göre ölçeğin bütününde anlamlı farklılık göstermektedir [ $X^{2}$ $(3)=8.893 ; p<.05]$. Analizler sonucunda 1,3 ve 4 . sinıftaki katılımcıların canlı ders 
etkileşim düzeylerinin 2. sınıftaki katılımcılara göre daha olumlu düzeyde olduğu söylenebilir. Bununla beraber ölçeğin tüm alt boyutları için canlı ders etkileşim düzeylerinin sınıf düzeyi değişkenine göre anlamlı farklılık göstermediği sonucuna ulaşılmıştır.

Türkçe öğretmeni adaylarının ekran okuma öz yeterlik algı düzeylerinin akademik başarı düzeyi değişkeni açısından farklılaşıp farklılaşmadığını belirlemek amacıyla Kruskal Wallis H-testi uygulanmıştır. Uygulanan testler sonucunda elde edilen sonuçlar Tablo 11' de gösterilmiştir.

Tablo 11: Türkçe Öğretmeni Adaylarının Ekran Okuma Öz Yeterlik Algı Düzeylerinin Akademik Başarı Düzeyi Değişkenine Göre Kruskal Wallis H-testi Analiz Sonuçları

\begin{tabular}{|c|c|c|c|c|c|c|}
\hline Boyutlar & Gruplar & $\mathbf{N}$ & $\begin{array}{c}\text { Sira } \\
\text { Ortalaması }\end{array}$ & Sd & $X^{2}$ & p* \\
\hline \multirow[t]{3}{*}{ Kullanışlilık } & $0-2,49$ & 11 & 161.91 & 3 & 23.145 & .000 \\
\hline & $2,50-2,99$ & 48 & 79.08 & & & \\
\hline & $3,00-4,00$ & 151 & 109.79 & & & \\
\hline \multirow[t]{3}{*}{ Anlama } & $0-2,49$ & 11 & 147.18 & 3 & 6.896 & .032 \\
\hline & $2,50-2,99$ & 48 & 104.24 & & & \\
\hline & $3,00-4,00$ & 151 & 102.86 & & & \\
\hline \multirow[t]{3}{*}{ Sayfayı Yönetme } & $0-2,49$ & 11 & 145.00 & 3 & 7.038 & .030 \\
\hline & $2,50-2,99$ & 48 & 98.65 & & & \\
\hline & $3,00-4,00$ & 151 & 104.80 & & & \\
\hline \multirow[t]{3}{*}{ Göz Sağlı̆̆1 } & $0-2,49$ & 11 & 113.59 & 3 & 1.386 & .500 \\
\hline & $2,50-2,99$ & 48 & 97.72 & & & \\
\hline & $3,00-4,00$ & 151 & 107.38 & & & \\
\hline \multirow{3}{*}{$\begin{array}{l}\text { Ekran Okuma Öz } \\
\text { Yeterlik Alg1 Ölçeği }\end{array}$} & $0-2,49$ & 11 & 153.86 & 3 & 10.701 & $.005^{*}$ \\
\hline & $2,50-2,99$ & 48 & 92.45 & & & \\
\hline & $3,00-4,00$ & 151 & 106.13 & & & \\
\hline
\end{tabular}

Tablo 11 'de görüldüğü üzere Türkçe öğretmeni adaylarının ekran okuma öz yeterlik alg1 düzeylerinin akademik başarı düzeyine göre ölçeğin bütününde anlamlı farklılık göstermektedir $\left[X^{2}(3)=10.701 ; \mathrm{p}<.05\right]$. Analizler sonucunda not ortalaması $0-2,49$ puan aralığında olan katılımcıların ekran okuma öz yeterlik algı düzeylerinin diğer katılımcılara göre daha olumlu düzeyde olduğu söylenebilir. Bununla beraber kullanışlılık $\left[X^{2}(3)=23.145 ; \mathrm{p}<.05\right]$, anlama $\left[X^{2}(3)=6.896 ; \mathrm{p}<.05\right]$ ve sayfayı yönetme $\left[X^{2}(3)=7.038 ; \mathrm{p}<.05\right]$ alt boyutlarında da anlamlı farklılık göstermektedir. Analizler sonucunda akademik başarı düzeyi değişkenine göre ölçeğin bütününde olduğu gibi not ortalaması 0-2,49 puan aralığında olan katılımcıların ekran okuma öz yeterlik alg1 düzeylerinin diğer katılımcılara göre daha olumlu düzeyde olduğu söylenebilir. Ayrıca göz sağlığı alt boyutunda ekran okuma öz yeterlik alg1 düzeylerinin akademik başarı düzeyi değişkenine göre anlamlı farklılık göstermediği sonucuna ulaşılmıştır.

Türkçe öğretmeni adaylarının canlı ders etkileşim düzeylerinin akademik başarı düzeyi değişkeni açısından farklılaşıp farklılaşmadığını belirlemek amacıyla Kruskal 
Wallis H-testi uygulanmıştır. Uygulanan testler sonucunda elde edilen sonuçlar Tablo 12' de gösterilmiştir.

Tablo 12: Türkçe Öğretmeni Adaylarının Ekran Okuma Öz Yeterlik Algı Düzeylerinin Akademik Başarı Düzeyi Değişkenine Göre Kruskal Wallis H-testi Analiz Sonuçları

\begin{tabular}{|c|c|c|c|c|c|c|}
\hline Boyutlar & Gruplar & $\mathbf{N}$ & $\begin{array}{c}\text { Sıra } \\
\text { Ortalaması }\end{array}$ & Sd & $X^{2}$ & $p^{*}$ \\
\hline \multirow[t]{3}{*}{ Öğrenci } & $0-2,49$ & 11 & 110.45 & 3 & 16.029 & $.000 *$ \\
\hline & $2,50-2,99$ & 48 & 77.13 & & & \\
\hline & $3,00-4,00$ & 151 & 114.16 & & & \\
\hline \multirow[t]{3}{*}{ Öğretmen } & $0-2,49$ & 11 & 115.95 & 3 & 12.821 & $.002 *$ \\
\hline & $2,50-2,99$ & 48 & 82.36 & & & \\
\hline & $3,00-4,00$ & 151 & 112.09 & & & \\
\hline \multirow[t]{3}{*}{ İçerik } & $0-2,49$ & 11 & 92.64 & 3 & 43.123 & $.000 *$ \\
\hline & $2,50-2,99$ & 48 & 76.21 & & & \\
\hline & $3,00-4,00$ & 151 & 115.75 & & & \\
\hline \multirow[t]{3}{*}{ Sunum Şekli } & $0-2,49$ & 11 & 76.68 & 3 & 32.535 & $.000 *$ \\
\hline & $2,50-2,99$ & 48 & 68.88 & & & \\
\hline & $3,00-4,00$ & 151 & 119.24 & & & \\
\hline Canlı Ders & $0-2,49$ & 11 & 81.86 & 3 & 60.609 & $.000 *$ \\
\hline \multirow[t]{2}{*}{ Etkileşim Düzeyi } & $2,50-2,99$ & 48 & 61.65 & & & \\
\hline & $3,00-4,00$ & 151 & 121.16 & & & \\
\hline
\end{tabular}

Tablo 12'de görüldüğü üzere Türkçe öğretmeni adaylarının canlı ders etkileşim düzeylerinin akademik başarı düzeyine göre ölçeğin bütününde anlamlı farklılık göstermektedir $\left[X^{2}(3)=60.609 ; \mathrm{p}<.05\right]$. Analizler sonucunda not ortalaması $3,00-4,00$ puan aralı̆̆ında olan katılımcıların canlı ders etkileşim düzeylerinin diğer katılımcılara göre daha olumlu düzeyde olduğu söylenebilir. Bununla beraber içerik $\left[X^{2}\left({ }_{3}\right)=43.123\right.$; $\mathrm{p}<.05]$ ve sunum şekli $\left[X^{2}\left({ }_{3}\right)=32.535 ; \mathrm{p}<.05\right]$ alt boyutlarında da anlamlı farklılık göstermektedir. Analizler sonucunda not ortalaması 3,00-4,00 puan aralığında olan katılımcıların canlı ders etkileşim düzeylerinin diğer katılımcılara göre daha olumlu düzeyde olduğu söylenebilir. Ayrıca öğrenci $\left[X^{2}(3)=16.029 ; \mathrm{p}<.05\right]$ ve öğretmen [ $X^{2}$ $(3)=12.821 ; \mathrm{p}<.05]$ alt boyutlarında da anlamlı farklılık göstermektedir. Analizler sonucunda not ortalaması $0-2,49$ puan aralığı ve 3,00-4,00 puan aralığında olan katılımcıların canlı ders etkileşim düzeylerinin not ortalaması 2,50-2,99 puan aralığı katılımcılara göre daha olumlu düzeyde olduğu söylenebilir.

Türkçe öğretmeni adaylarının ekran okuma öz yeterlik algı düzeylerinin bir günde ortalama internette geçirilen süre değişkeni açısından farklılaşıp farklılaşmadığını belirlemek amacıyla Kruskal Wallis $\mathrm{H}$-testi uygulanmıştır. Uygulanan testler sonucunda elde edilen sonuçlar Tablo 13' te gösterilmiş̧ir. 
Türkçe Öğretmeni Adaylarının Canlı Ders Etkileşim Düzeyi ile Ekran Okuma Özyeterlikleri Arasındaki İlişkinin İncelenmesi

Tablo 13: Türkçe Öğretmeni Adaylarının Ekran Okuma Öz Yeterlik Algı Düzeylerinin Bir Günde Ortalama İnternette Geçirilen Süre Değişkenine Göre Kruskal Wallis H-testi Analiz Sonuçları

\begin{tabular}{|c|c|c|c|c|c|c|}
\hline Boyutlar & Gruplar & $\mathbf{N}$ & $\begin{array}{c}\text { Sira } \\
\text { Ortalaması } \\
\end{array}$ & Sd & $X^{2}$ & $\mathbf{p}^{*}$ \\
\hline \multirow[t]{4}{*}{ Kullanışlılık } & $0-2$ saat & 16 & 121.34 & 3 & 13.766 & $.003 *$ \\
\hline & $2-4$ saat & 86 & 93.61 & & & \\
\hline & 4-6 saat & 88 & 119.23 & & & \\
\hline & 6 s. üstü & 20 & 83.55 & & & \\
\hline \multirow[t]{4}{*}{ Anlama } & $0-2$ saat & 16 & 130.63 & 3 & 14.957 & $.002 *$ \\
\hline & 2-4 saat & 86 & 90.34 & & & \\
\hline & 4-6 saat & 88 & 117.55 & & & \\
\hline & 6 s. üstü & 20 & 97.60 & & & \\
\hline \multirow[t]{4}{*}{ Sayfayı Yönetme } & $0-2$ saat & 16 & 78.78 & 3 & 21.577 & $.000 *$ \\
\hline & $2-4$ saat & 86 & 124.79 & & & \\
\hline & 4-6 saat & 88 & 91.90 & & & \\
\hline & 6 s. üstü & 20 & 103.75 & & & \\
\hline \multirow[t]{4}{*}{ Göz Sağlığ 1} & $0-2$ saat & 16 & 110.84 & 3 & 9.005 & $.029 *$ \\
\hline & $2-4$ saat & 86 & 92.17 & & & \\
\hline & 4-6 saat & 88 & 116.70 & & & \\
\hline & 6 s. üstü & 20 & 109.25 & & & \\
\hline \multirow{4}{*}{$\begin{array}{l}\text { Ekran Okuma Öz } \\
\text { Yeterlik Alg1 Ölçeği }\end{array}$} & $0-2$ saat & 16 & 119.78 & 3 & 10.078 & $.018 *$ \\
\hline & 2-4 saat & 86 & 92.79 & & & \\
\hline & 4-6 saat & 88 & 117.59 & & & \\
\hline & 6 s. üstü & 20 & 95.55 & & & \\
\hline
\end{tabular}

Tablo 13'te görüldüğü üzere Türkçe öğretmeni adaylarının ekran okuma öz yeterlik alg1 düzeylerinin bir günde ortalama internette geçirilen süreye göre ölçeğin bütününde anlamlı farklılık göstermektedir $\left[X^{2}\left({ }_{3}\right)=10.078 ; \mathrm{p}<.05\right]$. Analizler sonucunda bir günde ortalama 0-2 ve 4-6 saat internette zaman geçiren katılımcıların ekran okuma öz yeterlik alg1 düzeylerinin diğer katılımcılara göre daha olumlu düzeyde olduğu söylenebilir. Bununla beraber kullanışlılık $\left[X^{2}(3)=13.766 ; \mathrm{p}<.05\right]$ ve anlama $\left[X^{2}\left({ }_{3}\right)=14.957 ; \mathrm{p}<.05\right]$ alt boyutlarında da anlamlı farklılık göstermektedir. Analizler sonucunda ölçeğin bütününde olduğu gibi bir günde ortalama 0-2 ve 4-6 saat internette zaman geçiren katılımcıların ekran okuma öz yeterlik algı düzeylerinin diğer katılımcılara göre daha olumlu düzeyde olduğu söylenebilir. Sayfayı yönetme $\left[X^{2}(3)=21.577 ; \mathrm{p}<.05\right]$ alt boyutunda da anlamlı farklılık göstermektedir. Analizler sonucunda bir günde ortalama 2-4 ve 6 saat ve üzerinde internette zaman geçiren katılımcıların ekran okuma öz yeterlik alg1 düzeylerinin diğer katılımcılara göre daha olumlu düzeyde olduğu söylenebilir. Ayrıca göz sağlığ $\left.{ }_{1} X^{2}(3)=9.005 ; \mathrm{p}<.05\right]$ alt boyutunda da anlamlı farklılık göstermektedir. Analizler sonucunda bir günde ortalama 2-4 saat internette zaman geçiren katılımcıların dışındakilerin ekran okuma öz yeterlik algı düzeylerinin daha olumlu düzeyde olduğu söylenebilir. 
Türkçe öğretmeni adaylarının canlı ders etkileşim düzeylerinin internette geçirilen süre değişkeni açısından farklılaşıp farklılaşmadığını belirlemek amacıyla Kruskal Wallis H-testi uygulanmıştır. Uygulanan testler sonucunda elde edilen sonuçlar Tablo 14 ' da gösterilmiştir.

Tablo 14: Türkçe Öğretmeni Adaylarının Canlı Ders Etkileşim Düzeylerinin Bir Günde Ortalama İnternette Geçirilen Süre Değişkenine Göre Kruskal Wallis H-testi Analiz Sonuçları

\begin{tabular}{|c|c|c|c|c|c|c|}
\hline Boyutlar & Gruplar & $\mathbf{N}$ & $\begin{array}{c}\text { Sıra } \\
\text { Ortalaması }\end{array}$ & Sd & $X^{2}$ & p* \\
\hline \multirow[t]{4}{*}{ Öğrenci } & $0-2$ saat & 16 & 80,97 & 3 & 63.475 & $.000 *$ \\
\hline & 2-4 saat & 86 & 73,27 & & & \\
\hline & 4-6 saat & 88 & 138,72 & & & \\
\hline & 6 s. üstü & 20 & 117,55 & & & \\
\hline \multirow[t]{4}{*}{ Öğretmen } & $0-2$ saat & 16 & 48,00 & 3 & 43.760 & $.000 *$ \\
\hline & 2-4 saat & 86 & 128,19 & & & \\
\hline & 4-6 saat & 88 & 92,07 & & & \\
\hline & 6 s. üstü & 20 & 113,03 & & & \\
\hline \multirow[t]{4}{*}{ İçerik } & $0-2$ saat & 16 & 61,28 & 3 & 24.887 & $.000 *$ \\
\hline & 2-4 saat & 86 & 108,43 & & & \\
\hline & 4-6 saat & 88 & 109,48 & & & \\
\hline & 6 s. üstü & 20 & 110,75 & & & \\
\hline \multirow[t]{4}{*}{ Sunum Şekli } & $0-2$ saat & 16 & 103,25 & 3 & 22.916 & $.000 *$ \\
\hline & 2-4 saat & 86 & 125,13 & & & \\
\hline & 4-6 saat & 88 & 95,51 & & & \\
\hline & 6 s. üstü & 20 & 66,85 & & & \\
\hline \multirow{4}{*}{$\begin{array}{l}\text { Canlı Ders Etkileşim } \\
\text { Düzeyi }\end{array}$} & $0-2$ saat & 16 & 70,00 & 3 & 11.723 & $.008 *$ \\
\hline & 2-4 saat & 86 & 106,68 & & & \\
\hline & 4-6 saat & 88 & 112,69 & & & \\
\hline & 6 s. üstü & 20 & 97,20 & & & \\
\hline
\end{tabular}

Tablo 14'de görüldüğü üzere Türkçe öğretmeni adaylarının canlı ders etkileşim düzeylerinin bir günde ortalama internette geçirilen süreye göre ölçeğin bütününde anlamlı farklılık göstermektedir $\left[X^{2}(3)=11.723 ; \mathrm{p}<.05\right]$. Analizler sonucunda bir günde ortalama 2-4 ve 4-6 saat internette zaman geçiren katılımcıların canlı ders etkileşim düzeylerinin diğer katılımcılara göre daha olumlu düzeyde olduğu söylenebilir. Bununla beraber öğretmen $\left[X^{2}\left({ }_{3}\right)=43.760 ; \mathrm{p}<.05\right]$ ve sunum şekli $\left[X^{2}\left({ }_{3}\right)=22.916 ; \mathrm{p}<.05\right]$ alt boyutlarında 2-4 saat internette zaman geçiren katılımcıların canlı ders etkileşim düzeylerinin diğer katılımcılara göre daha olumlu düzeyde olduğu söylenebilir. Öğrenci alt boyutunda ise 4-6 saat internette zaman geçiren katılımcıların canlı ders etkileşim düzeylerinin diğer katılımcılara göre daha olumlu düzeyde olduğu söylenebilir. 
Türkçe Öğretmeni Adaylarının Canlı Ders Etkileşim Düzeyi ile Ekran Okuma Özyeterlikleri Arasındaki İlişkinin Íncelenmesi

Tablo 15. Türkçe Öğretmeni Adaylarının Ekran Okuma Öz Yeterlik Algı Düzeyleri ile Canlı Ders Etkileşim Düzeyleri Arasındaki İlişkiye Yönelik Spearman Korelasyon Analizi

\begin{tabular}{llll}
\hline & & Yazma & Okuma \\
\hline Yazma & Spearman Correlation & 1000 & .328 \\
& Sig. (2-tailed) & & $.000^{*}$ \\
Okuma & N & 210 & 210 \\
& Spearman Correlation & .328 & 1000 \\
& Sig. (2-tailed) & $.000^{*}$ & \\
& N & 210 & 210 \\
\hline
\end{tabular}

*p<.01 düzeyinde anlamlı fark vardır.

Tablo $15^{\prime}$ da görüldüğü üzere Türkçe eğitimi öğretmen adaylarının akademik okuryazarlık düzeyleri ile teknoloji yeterliği arasında zayıf düzeyde, pozitif ve anlamlı bir ilişki olduğu görülmektedir $[\mathrm{r}=0.328, \mathrm{p}<.01]$. Buna göre öğretmen adaylarının canlı ders etkileşim düzeyleri arttıkça ekran okuma öz yeterliklerinin de arttığı söylenebilir.

\section{Sonuç, Tartışma ve Öneriler}

Bu araştırmada Türkçe öğretmeni adaylarının canlı ders etkileşim düzeyleri ile ekran okuma öz yeterlikleri arasındaki ilişki belirlenmeye çalışılmıştır. Araştırmaya Çanakkale Onsekiz Mart Üniversite'sinde öğrenim gören 210 öğretmen adayı katılmıștır. Katılımcıların \%78.1'ini kadın, \% 21.9'unu erkek öğretmen adayları oluşturmaktadır. Katılımcıların \%20.0'sini birinci sınıf, \%16.2'sini ikinci sınıf, \%29.0'unu üçüncü sınıf, \%34.8'ini ise dördüncü sınıf öğrencileri olușturmaktadır. Katılımcıların \%5.2'si 0-2.49 puan, \%22.9'u 2.50-2.99 puan ve \%71.9'u 3.00-4.00 puan aralığında akademik başarı puanına sahiptir. Bir günde katılımcıların \%7.6'sı 0-2 saat, \%41.0'i 2-3 saat, \%41.9'u 46 saat, $\% 9.5$ 'i ise altı ve altı üzeri saat internette vakit geçirmektedir.

Türkçe eğitimi öğretmen adaylarının canlı ders etkileşim düzeyi algısı ile ekran okuma öz yeterlikleri arasında zayıf düzeyde, pozitif yönde ve istatistiksel olarak anlamlı bir ilişki olduğu belirlenmiştir. Başka bir ifade birindeki değişim diğerini de zayıf düzeyde etkilemektedir. Buna göre öğretmen adaylarının canlı ders etkileşim düzeyleri ile ekran okuma öz yeterliklerinin birbirini olumlu yönde etkilediği söylenebilir.

Türkçe öğretmeni adaylarının canlı ders etkileşim düzeyi algılarının yüksek seviyede olduğu sonucuna ulaşılmıştır. Aslan'ın (2021) çalışmasında da benzer şekilde katılımcıların canlı ders etkileşim düzeyleri yüksek düzeyde çıkmıştır. Araştırmanın bulgularından hareketle araştırmaya katılan Türkçe öğretmeni adaylarında erkek adayların canlı ders etkileşim düzeyi algılarının kadınlara göre daha yüksek düzeyde olduğu sonucuna ulaşılmıştır. Bununla beraber öğrenci ve sunum şekli alt boyutlarında canlı ders etkileşim düzeyi algıları erkeklerin lehine anlamlı bir fark gösterirken öğretmen alt boyutunda ise kadınların lehinedir. 1, 3 ve 4. sınıftaki katılımcıların canlı ders etkileşim düzeylerinin 2. sınıftaki katılımcılara göre daha olumlu düzeyde olduğu sonucuna ulaşılmıştır. Ayrıca ölçeğin tüm alt boyutları için katılımcıların canlı ders etkileşim düzeyi algılarının sınıf düzeyi değişkenine göre anlamlı farklılık göstermediği 
sonucuna ulaşı1mıştır. Not ortalaması 3,00-4,00 puan aralı̆ğında olan katılımcıların canlı ders etkileşim düzeyi algılarının diğer katılımcılara göre daha olumlu düzeyde olduğu sonucuna ulaşılmıştır. İçerik ve sunum şekli alt boyutlarında not ortalaması 3,00-4,00 puan aralığında olan katılımcıların canlı ders etkileşim düzeyi algılarının diğer katılımcılara göre daha olumlu düzeyde olduğu sonucuna ulaşılmıştır. Öğrenci ve öğretmen alt boyutlarında not ortalaması $0-2,49$ puan aralığ 1 ve 3,00-4,00 puan aralığında olan katılımcıların canlı ders etkileşim düzeyi algılarının not ortalaması 2,50-2,99 puan aralığında olan katılımcılara göre daha olumlu düzeyde olduğu sonucuna ulaşılmıştır. Bir günde ortalama 2-4 ve 4-6 saat internette zaman geçiren katılımcıların canlı ders etkileşim düzeyi algılarının diğer katılımcılara göre daha olumlu düzeyde olduğu sonucuna ulaşılmıştır. Bununla beraber öğretmen ve sunum şekli alt boyutlarında 2-4 saat internette zaman geçiren katılımcıların canlı ders etkileşim düzeyi algılarının diğer katılımcılara göre daha olumlu düzeyde olduğu sonucuna ulaşılmıştır. Öğrenci alt boyutunda ise 4-6 saat internette zaman geçiren katılımcıların canlı ders etkileşim düzeyi algılarının diğer katılımcılara göre daha olumlu düzeyde olduğu sonucuna ulaşılmıştır.

Türkçe öğretmeni adaylarının ekran okuma öz yeterlik algı düzeylerinin yüksek seviyede olduğu sonucuna ulaşılmıştır. Bu sonuç literatürdeki iki çalışma ile eşleşirken bir çalışma ile eşleşmemektedir. Gömleksiz, Kan ve Fidan (2013: 152) ile Demirci, Özler ve Karaduman'ın (2021: 162) çalışmalarında ekran okuma öz yeterliği algısı yüksek düzeyde, Ulu ve Zelzele'nin (2018: 2620) çalışmalarında ise orta düzeyde tespit edilmiştir. Araştırmanın bulgularından hareketle araştırmaya katılan Türkçe öğretmeni adaylarında erkek adayların ekran okuma öz yeterlik algı düzeylerinin kadınlara göre daha yüksek düzeyde olduğu sonucuna ulaşılmıştır. Gömleksiz, Kan ve Fidan'ın (2013: 154) araştırmasında erkek öğretmen adaylarının kadınlara göre ekran okumanın daha yararlı olduğu algısına sahip olduğu sonucuna ulaşılmış̧ır. Bu sonuçlar birbirlerini desteklemektedir. Ancak Ulu ve Zelzele'nin (2018: 2620) çalışmalarında ise cinsiyet değişkenine göre kadınların lehine sonuç bulunmuştur. Demirci, Özler ve Karaduman'ın (2021: 163) çalışmalarında ise cinsiyet değişkeni ekran okuma öz yeterlik algısını etkilememektedir. Bu araştırmada kullanışlılık, anlama ve göz sağlığı alt boyutlarında ekran okuma öz yeterlik algıları erkeklerin lehine anlamlı bir fark gösterirken sayfayı yönetme alt boyutunda ise kadınların lehine anlamlı bir farka ulaşılmıştır. Ulu ve Zelzele'nin (2018: 2621) çalışmalarında cinsiyet değişkenine göre kullanışl1lık ve göz sağlığı alt boyutlarında anlamlı bir farklılık gözlenmemiş ve anlama alt boyutunda ise cinsiyete göre kadın katılımcıların lehine anlamlı farklılığa ulaşılmıştır. 1 ve 4 . sınıftaki Türkçe öğretmeni adaylarının ekran okuma öz yeterlik algıları 2 ve 3. sınıftaki katılımcılara göre daha olumlu düzeyde olduğu sonucuna ulaşılmıştır. Ayrıca göz sağlığı alt boyutunda 2 ve 3 . sinıftaki katılımcılara göre 1 ve 4 . sinıftaki katılımcılar daha olumlu düzeyde ekran okuma öz yeterlik algılarına sahipken diğer alt boyutlarda sınıf düzeyi değişkenine göre anlamlı bir farklılığa ulaşılamamıştır. Ulu ve Zelzele'nin (2018: 2621) çalışmalarında ise sınıf düzeyi değişkenine göre anlamlı bir farklılık bulunamamıştır. Araştırmaya katılan Türkçe öğretmeni adaylarında not ortalaması 0-2,49 puan aralığında olan katılımcıların ekran okuma öz yeterlik algı düzeylerinin diğer katılımcılara göre daha olumlu düzeyde olduğu sonucuna ulaşılmıştır. Kullanışlılık, anlama ve sayfayı yönetme alt boyutlarında da ölçeğin bütününde olduğu gibi not ortalaması 0-2,49 puan 
aralığında olan katılımcıların ekran okuma öz yeterlik alg1 düzeylerinin diğer katılımcılara göre daha olumlu düzeyde olduğu sonucuna ulaşılmıştır. Ayrıca göz sağlığı alt boyutunda ekran okuma öz yeterlik algı düzeylerinin akademik başarı düzeyi değişkenine göre anlamlı farklılık göstermediği sonucuna ulaşılmıştır. Araştırmaya katılan Türkçe öğretmeni adaylarında bir günde ortalama 0-2 ve 4-6 saat internette zaman geçiren katılımcıların ekran okuma öz yeterlik algı düzeylerinin diğer katılımcılara göre daha olumlu düzeyde olduğu sonucuna ulaşılmıştır. Ulu ve Zelzele'nin (2018: 2623) çalışmalarında interneti kullanım süresine göre interneti ortalama 1-3 saat süresince kullanan adayların lehine anlamlı bir farklılığa ulaşılmıştır.

Türkçe öğretmeni adaylarının canlı ders etkileşim düzeyleri ile ekran okuma öz yeterlikleri ile ilgili yapılan analizlerin bulgularından hareketle cinsiyet, sınıf düzeyi, akademik başarı ve internette geçirilen süre değişkenlerine göre elde edilen sonuçların nedenleri ayrıntılı olarak araştırılmalıdır. Bu konuda nicel araştırmalardan sonra nitel yöntemlerle desteklenerek derinlemesine çalışmalar soru işaretlerinin çözümlenmesini sağlayacaktır. Böylelikle çevrimiçi derslerde etkileşim konusu ile ilgili alana katkı sağlanması söz konusu olacaktır.

Etkileşim hem yüz yüze örgün öğretimde hem de uzaktan eğitim kapsamında dijital ortamlarda verilen öğretimin sınanması ve etkililiğini arttırmak için çok önemlidir. Uzaktan eğitimin daha verimli olması için öğrenen, öğretici ve içeriğin etkileşimli olması gerekir. Etkileşimin istenen düzeyde olması için de dijital iletişim ve öğretmenin algıladığı anlık geri bildirimin güçlü olması gerekmektedir. Etkileşim, zayıflıkların anlaşılmasını sağlayarak eksikliklerin tamamlanmasına ve öğretimin güçlendirilmesine imkân sağlar. Etkileşim ile öğreten, öğrenenlerin anlık durumlarının farkına vararak anlatımın hızını ihtiyaca göre sabit tutabilir, arttırabilir veya azaltabilir. Etkileşim konusunda farkındalıklarının artırılması için daha ayrıntılı bilgiler paylaşılmak üzere öğrenenler için kurslar düzenlenip öğretenler için de hizmet içi eğitimler verilebilir.

Cumhuriyetten günümüze Türkçe öğretim programları günceli yakalamak amacıyla birçok defa yenilenmiştir (Güzel ve Karadağ, 2013, Özbay ve Özdemir, 2014; Temizyürek ve Balcı, 2015). Yeni medya araçlarının yaygınlaşması ile beraber ortaya çıkan ekran okuma becerisindeki ihtiyaçları karşılamak amacıyla da stratejik eğitimler ve program değişikliklerine ihtiyaç vardır. Sadece ilköğretim ve ortaöğretimde değil öğretmen yetiştirme kurumlarında da yeni medya araçlarından kaynaklanan ihtiyaçların farkında olunarak öğretmen yetiştirme programları kısmen güncellenmiştir. Teknoloji entegrasyonu yönünden teknolojik araçlarda okuma stratejilerine uygun ders materyallerinin hazırlaması ekran okumayı kâğıt okuma becerisinin başarısına ulaştıracağ 1 düşünülmektedir. FATİH projesine adapte olabilmiş ekran okuma yönünden farkındalığı olan ve yeni medya araçlarının gerektirdiği dil becerilerini öğrencilere öğretebilecek Türkçe öğretmenlerine ihtiyaç vardır (Akkaya ve Toprak, 2021; Baş ve Yıldırım, 2018; Elkıran, 2017; Geçgel, Kana, Öztürk ve Akkaş, 2020). Bu bağlamda eğitim öğretimin tüm kademelerinde ve öğretmen yetiştirmede yeni medyalardan doğan ekran okuma gibi yeni dil becerilerini dikkate alan iletişim becerileri kazandıran öğretim 
programlarının geliştirilmesinin ve sahadaki öğretmenlerin de bu yönde gerekli hizmet içi eğitimlere tabi tutulmasının faydalı olacağı düşünülmektedir.

\section{Kaynaklar}

Akkaya, A., ve Toprak, F. (2020) Görsel okuryazarlık karikatürlerle Türkçe dersi işleme süreci. Asos yayıncilik

Arat, T., ve Bakan, Ö. (2011). Uzaktan eğitim ve uygulamaları. Selçuk Üniversitesi Sosyal Bilimler Meslek Yüksekokulu Dergisi, 14(1-2), 363-374.

Aslan, A. (2021). Problem-based learning in live online classes: Learning achievement, problem-solving skill, communication skill, and interaction. Computers \& Education, 171, 104237. https://doi.org/10.1016/j.compedu.2021.104237

Baş, B., ve Yıldırım, T. (2018). Yabancılara Türkçe öğretiminde teknoloji entegrasyonu. Ana Dili Ĕgitimi Dergisi 6(3), 827 - 839.

Baştuğ, M., ve Keskin, H. (2012). Okuma Becerilerinin Okuma Ortamı Açısından Karşılaştırılması: Ekran mı kâğıt mı?. Atatürk Üniversitesi Sosyal Bilimler Enstitüsü Dergisi, 16(3), 73-83.

Bozkurt, A. (2016). Öğrenme analitiği: e-öğrenme, büyük veri ve bireyselleştirilmiş öğrenme. Açıkögretim Uygulamaları ve Araştırmaları Dergisi, 2(4), 55-81.

Büyüköztürk, Ş., Çakmak, E., Akgün, Ö. E., Karadeniz, Ş., ve Demirel, F. (2011). Eğitimde bilimsel araştırma yöntemleri. Pegem akademi.

Demirci, C., Özler, A., ve Karaduman, E. (2021) Teachers' attitude and self-efficacy perceptions towards screen reading. Osmangazi Journal of Educational Research, 8(1), 150-167.

Elkıran, Y.M. (2017). Türkçe Öğretmeni Adaylarının Bilgi ve İletişim Teknolojilerini Kullanımlarının İncelenmesi. International Journal of Innovative Approaches in Education, 1(1), 45-58.

Fırat, M. (2015). Eğitim teknolojileri araştırmalarında yeni bir alan: öğrenme analitikleri. Mersin Üniversitesi Eğitim Fakültesi Dergisi, 11(3).

Geçgel, H., Kana, F., Öztürk, N. E., ve Akkaş, İ. (2020). Öğretmen adaylarının okuma motivasyonları ve sosyal medyaya özgü epistemolojik inançları arasındaki ilişkinin incelenmesi. Dil Ĕgitimi ve Araştırmaları Dergisi, 6(2), 478-507.

George, D., ve Mallery, P. (2010). SPSS for Windows step by step. A simple study guide and reference (10. Baskl). GEN, Boston, MA: Pearson Education, Inc.

Gömleksiz, M.N., Kan, A.Ü. ve Fidan, E.K. (2013). Öğretmen adaylarının ekran okuma özyeterlik düzeylerine ilişkin görüşleri. Erzincan Üniversitesi Eğitim Fakültesi Dergisi, 15(2), 138-159.

Güneş, F. (2010). Öğrencilerde ekran okuma ve ekranik düşünme. Mustafa Kemal Üniversitesi Sosyal Bilimler Enstitüsü Dergisi, 7(14), 1-20. 
Güneş, F. (2016). Kağıttan ekrana okuma alanındaki gelişmeler. Bartın University Journal of Faculty of Education, 5(1), 1-18.

Güzel, A., ve Karadağ, Ö. (2013). Anlatma becerileri açısından "Türkçe Dersi Öğretim Programı (6, 7, 8. Sınıflar)" na eleştirel bir bakış. Ana Dili Ĕgitimi Dergisi, 1(1), 45 52.

Ifenthaler, D. (2017). Are higher education institutions prepared for learning analytics?. TechTrends 61, 366-371. https://doi.org/10.1007/s11528-016-0154-0

Karaman, E, G. (2015). Canlı Ders Etkileşim Düzeyi Belirleme Ölçeği’nin geliştirilmesi ve otomatik kestirim sisteminin tasarlanması. Yayımlanmamış Doktora tezi. Atatürk Üniversitesi, Eğitim Bilimleri Enstitüsü.

Karasar, N. (2002). Bilimsel araştırma yöntemi. Nobel yayın dağıtım.

Karatay, H. (2011). 4+1 planlı yazma ve değerlendirme modelinin öğretmen adaylarının yazılı anlatım tutumlarını ve yazma becerilerini geliştirmeye etkisi. Turkish Studies International Periodical for the Languages, Literature and History of Turkish or Turkic, 6(3), 1029-1047.

Kol, S., ve Schcolnik, M. (2000). Enhancing screen reading strategies. Calico journal, 67-80.

Kurudayığlu, M., ve Çimen, L. (2020). Yabancı dil olarak Türkçe öğrenen öğrencilerin akademik yazılarında etkileşimli üstsöylem belirleyicilerinin kullanımı. OPUS Uluslararası Toplum Araştırmaları Dergisi, 16(31), 3899-3923.

Maden, S. (2012). Ekran okuma türleri ve Türkçe öğretmeni adaylarının ekran okumaya yönelik görüşleri. Dil ve Edebiyat Eğitimi Dergisi, 1(3), 1.

Özbay, M., ve Özdemir, O. (2014). Türkçe öğretim programı için bir öneri:dijital okuryazarlığa yönelik amaç ve kazanımlar. Okuma Yazma Eğitimi Araştırmaları, 2(2), 31-40.

Temizyürek, F., ve Balcı, A. (2015). Cumhuriyet dönemi ilköğretim okulları türkçe programlarl. Nobel Yayıncılık

Tutsun, E. (2020). Öğrenme analitikleri ve yükseköğretimdeki uygulama alanları. Bilişim Teknolojileri Dergisi, 13(3), 243-254.

Ulu, H. (2018). Ekran okuma öz yeterlik alg1 ölçeği: Geçerlik ve güvenirlik çalışması. Ana Dili Eğitimi Dergisi, 6(1), 148-165.

Ulu, H. ve Zelzele, E. B. (2018). Öğretmen adaylarının ekran okuma öz yeterlik algılarının incelenmesi. Uluslararası Türkçe Edebiyat Kültür Eğitim (TEKE) Dergisi, 7(4), 2608-2628. 
Ustabulut, M.Y. (2021). SWOT Analysis for the Distance Education Process of Lecturers Teaching Turkish as a Foreign Language . Educational Policy Analysis and Strategic Research, 16(1), 139-152.

Yılmaz, F.G. ve Yilmaz, R. (2020). Student opinions about personalized recommendation and feedback based on learning analytics. Tech Know Learn 25, 753-768.

YÖK, (2013) Yükseköğretim kurumlarında uzaktan öğretime ilişkin usul ve esaslar. internet adresi:https://www.yok.gov.tr/Documents/Kurumsal/egitim_ogretim_dairesi/Uzakt an_ogretim/yuksekogretim_kurumlarinda_uzaktan_ogretime_iliskin_usul_ve_esasl ar.pdf erişim tarihi:25.04.2021 